\title{
Predictive Value of CDX2 and SOX2 in Chronic Gastritis and Intestinal-type Gastric Cancer
}

\author{
Noha Helal ${ }^{1 *}$, Zeinab Omran ${ }^{1}$, Tarek Aboushousha ${ }^{1}$, Magdy Youssef ${ }^{2}$, Afkar Badawy ${ }^{1}$, Ayman Abdel Aziz ${ }^{2}$, \\ Mohammed Aboul-Ezz ${ }^{2}$, Mona M. Moussa ${ }^{1}$ \\ ${ }^{1}$ Department of Pathology, Theodor Bilharz Research Institute, Warraq Al Hadar, Giza, Egypt; ${ }^{2}$ Department of Hepatology and \\ Gastroenterology, Theodor Bilharz Research Institute, Warraq Al Hadar, Giza, Egypt
}

\section{Abstract}

Edited by: Sinisa Stojanosk Citation: Helal N, Omran Z, Aboushousha T, Youssef M Badawy A, Aziz AA, Aboul-Ezz M, Moussa MM. Predictive Value of CDX2 and SOX2 in Chronic Gastritis an Med Sci. 2020 Feb 05; 8(A):947-955. https:///doi.org/10.3889/ oamjms. 2020.5570 Keywords: CDX2; SOX2; Chronic Gastritis; Gastric Cancer; Helicobacter pylori; Intestinal Metaplasia

*Correspondence: Noha S. Helal, Department of Pathology, Theodor Bilharz Research Institute, El-Nile Street, Warrak El-Hadar, Imbaba, Giza - 12411, Egypt. E-mail: nohasaidhelal@yahoo.com Received: 12-Nov-2020 Revised: 09-Dec-2020 Copyright: ๑ 2020 Noha Helal Z Zinab Omran, Copyright. 2020 Accepted: $14-D$ cc-2020 Abdel Aziz, Mohammed Aboul-Ezz, Mona M. Mouss, Funding: This work was financed by TBRI internal project No.114T. Principal investigator: Assistant Prof. Dr. Zeinab Omran. Competing Interests: The authors have declared that no Open Access: This is an open-access article distributed under the terms of the Creative Commons Attribution-
BACKGROUND: Worldwide gastric cancer (GC) ranks sixth in incidence and second in mortality among al malignancies. CDX2 has an essential role in the development and maintenance of intestinal differentiation in the gut and ectopic sites such as intestinal metaplasia (IM) of the stomach. SOX2 contributes to the cell lineages normally found in the stomach, suggesting contribution in gastric differentiation.

AIM: The aim of the study was to assess the expression of CDX2 and SOX2 in chronic gastritis (CG) lesions associated with Helicobacter pylori, IM, or dysplasia as well as in intestinal-type GC

METHODS: Immunohistochemicalstaining for CDX2 and SOX2 were applied on archival paraffin blocks from 80 CG cases, 40 intestinal-type GC cases, and 10 controls. CG cases were either of non-specific inflammation or associated with $H$. pylori infection. GC cases were of intestinal-type only, excluding any other type of GC. Contro cases were of minimal gastritis, negative for $H$. pylori, IM, and dysplasia.

RESULTS: CDX2 expression was correlated with CG associated with $H$. pylori, IM, and dysplasia as well as with more differentiated and less invasive pattern of intestinal-type GC, while SOX2 expression was correlated with CG negative for $H$. pylori and IM as well as with less differentiated and more invasive intestinal-type GC.

CONCLUSION: Both CDX2 and SOX2 could predict the behavior of CG disease over time and plan the suitable line of treatment and both proteins could be potential targets for novel therapeutic interventions.

\section{Introduction}

According toGLOBOCAN 2018 data, the incidence of gastric cancer (GC) ranks sixth and mortality ranks second [1]. Although GC prevalence has shown a continuous reduction since the last midcentury, it is still a common malignancy and a frequent cause of cancer-related deaths [2]. Both histological types of GC: Intestinal and diffuse, present distinct morphological, clinical, and epidemiological features and are thought to develop from the activation of independent molecular mechanisms. Intestinal GC develops through a sequence of histological changes, including diffuse chronic gastritis (CG), mucosal atrophy, intestinal metaplasia (IM), dysplasia, and finally invasive carcinoma [3].

Helicobacter pylori are Gram-negative spirochetes which infect more than half of the world's population, likely due to water contamination and less sanitary living conditions [4]. Infection with $H$. pylori and the resulting chronic inflammation is a major step in the initiation and development of almost $90 \%$ of new cases of GC [5]. The pathogenicity of $H$. pylori is attributed largely to its various virulence components [6]. Chronic infection with $H$. pylori gives rise to IM which is the most relevant pre-neoplastic lesion of the stomach affecting about $30 \%$ of the individuals infected with $H$. pylori [7].

CDX2 is an intestine-specific homeobox transcription factor which is expressed in the intestinal epithelial cells from duodenum to the rectum [8] and has an essential role in the development and maintenance of intestinal differentiation in the gut and ectopic sites such as IM of the stomach and esophagus [9]. It regulates many cellular processes such as cell differentiation, proliferation, cell adhesion, migration, and tumor genesis [10]. Its role as a prognostic marker in colorectal carcinomas is well known, whereas its role in the outcome of gastric carcinomas is not yet established [11].

SOX2 is a member of the SOX (SRY-related HMG Box) family of transcription factors that play diverse roles, starting from orchestrating the mammalian embryogenesis [12], later on contributing to the normal morphogenesis and homeostasis of the foregut-derived 
epithelia of the esophagus, lung, and trachea [13]. It has been shown, in mice, that SOX2 expression contributes to all the cell lineages normally found in the stomach, suggesting an important contribution for gastric differentiation [14]. In addition, abnormal expression of SOX2 has been observed in tumors of the brain, breast, lung, and esophagus. However, in the GC context, its role remains puzzling and needs further clarification. Furthermore, its interplay with CDX2 remains unexplored [15].

This work aims to assess the expression of CDX2 and SOX2 as intestinal and gastric differentiation markers, respectively, in intestinal-type GCs and precancerous conditions, namely, chronic $H$. pylori infection, IM, and dysplasia, to evaluate the role of these markers as prognostic indicators of progression to gastric carcinoma.

\section{Materials and Methods}

\section{Samples}

This retrospective study included formalinfixed paraffin-embedded blocks of 130 specimens of endoscopic and surgically resected gastric lesions, divided as 10 blocks for control cases with minimal gastritis, negative for $H$. pylori, IM, and dysplasia; 80 blocks of cases with CG and 40 intestinal-type GC blocks. Blocks were collected from the Pathology Department, Theodor Bilharz Research Institute, in a period from January 2017 to October 2019.

Specimens of CG cases were obtained as endoscopic biopsies, while specimens of GC cases were obtained as partial/total gastrectomy specimens.

Table 1: Patients' characteristics in studied groups

\begin{tabular}{|c|c|c|c|c|c|}
\hline \multirow[t]{2}{*}{ Groups } & \multirow[t]{2}{*}{$\mathrm{n}$} & \multicolumn{2}{|l|}{ Gender } & \multirow{2}{*}{$\frac{\text { Age }}{\text { Mean } \pm S D}$} & \multirow[t]{2}{*}{$p$ value } \\
\hline & & Male n (\%) & Female $\mathrm{n}(\%)$ & & \\
\hline Control & 10 & $7(70)$ & $3(30)$ & $45.20 \pm 16.37^{*}$ & $p<0.01$ \\
\hline Chronic gastritis & 80 & $44(55)$ & $36(45)$ & $51.92 \pm 16.43^{*}$ & $p<0.001$ \\
\hline Intestinal-type GC & 40 & $26(65)$ & $14(35)$ & $60.95 \pm 6.86$ & \\
\hline Total & 130 & 77 (59.2) & $53(40.8)$ & & \\
\hline
\end{tabular}

Patients' characteristics were summarized in Table 1 and clinicopathological parameters of studied cases were shown in Table 2.

Table 2: Clinicopathological parameters

\begin{tabular}{llll}
\hline Patients groups & & & n. (\%) \\
\hline Control (10) & & & 10 \\
Chronic gastritis (80) & Intensity of inflammation & Mild & $28(35)$ \\
& & Moderate & $52(65)$ \\
Associated lesions & H. pylori infection & Present & $44(55)$ \\
& & Absent & $36(45)$ \\
& IM & Present & $34(42.5)$ \\
& \multirow{2}{*}{ Dysplasia } & Absent & $46(57.5)$ \\
Intestinal-type & \multirow{2}{*}{ Grade of differentiation } & Present & $10(12.5)$ \\
GC (40) & & Absent & $70(87.5)$ \\
& \multirow{2}{*}{ Stage of invasion } & Low grade & $29(72.5)$ \\
& & High grade & $11(27.5)$ \\
& & Early stage & $27(67.5)$ \\
& & Advanced stage & $13(32.5)$ \\
& & $33(82.5)$ \\
N: Number, H. pylori: Helicobacter pylori, IM: Intestinal metaplasia, GC: Gastric cancer & $7(17.5)$ \\
\hline
\end{tabular}

The protocol of this study was approved by the Institutional Review Board of Theodor Bilharz Research Institute for the protection of human subject and adopted by the $18^{\text {th }}$ world medical assembly, Helsinki, Finland (2013).

\section{evaluation}

\section{Histopathological technique and}

Paraffin sections from different gastric lesions were cut in $4 \mu \mathrm{m}$ thickness stained using hematoxylin and eosin (H\&E) for routine histopathological examination and diagnosis. Giemsa stain was used for the detection of $H$. pylori micro-organisms.

CG sections were evaluated for intensity of inflammation, presence/absence of $H$. pylori, IM and dysplasia.

Sections of gastric carcinoma were examined for tumor grading and staging according to International Histological Classification proposed by the World Health Organization, 2019. GC is considered as low grade (well-differentiated) or high grade (moderately or poorly differentiated) and is considered as either early (pT1) or advanced ( $\geq p T 2$ ) [16]. GCs of antrum were found in $31 / 40$ cases and that of corpus/funds in 9/40. All were of intestinal-type histology.

\section{Immunohistochemical technique}

One paraffin-embedded block was selected from each case and was cut into $4 \mu \mathrm{m}$ sections. The sections were put in the oven at $60^{\circ} \mathrm{C}$ for $4 \mathrm{~h}$, deparaffinized in xylene, rehydrated in a graded ethanol series, and treated with $3 \%$ hydrogen peroxide solution for $10 \mathrm{~min}$. Antigen retrieval was done by microwaving the tissue in $10 \mathrm{mmol} / \mathrm{L}$ citric acid buffer for $12 \mathrm{~min}$, then cooling at room temperature for $2 \mathrm{~h}$. The sections were incubated with an anti-CDX2 monoclonal antibody (code no. CMC23531040, Abcam, Cambridge, MA, USA) and anti-SOX2 monoclonal antibody (code no. ab97959, Abcam, Cambridge, MA, USA), at dilution of $1: 100$ for overnight at $4^{\circ} \mathrm{C}$. Sections were then washed 3 times for $5 \mathrm{~min}$ in phosphate-buffered saline. Non-specific staining was blocked with $0.5 \%$ casein and $5 \%$ normal serum for $30 \mathrm{~min}$ at room temperature. Finally, staining was developed with diaminobenzidine substrate and sections were counterstained with hematoxylin, dehydrated with graded ethanol, and mounted.

For each setting, positive and negative controls were routinely used. Negative controls were carried out in which phosphate-buffered saline was used instead of the primary antibody. Positive control slides were pancreatic tissue for CDX2 and squamous cell carcinoma of the lung for SOX2.

\section{Assessment of immunostaining}

The sections were examined using a light microscope (Scope A1, Axio, Zeiss, 
Germany). Photomicrographs were taken using a microscope-camera (AxioCam, MRc5, Zeiss, Germany). Two experienced pathologists independently examined nuclear CDX2 and SOX2 staining while blind to the clinicopathologic data of patients. At least 10 highpower fields at $\times 400$ were chosen randomly for each section. Cases with $>5 \%$ positive gastric/tumor cells in a section were regarded as positive expression. Both immunopositivity (number of positive cases) and extent of expression (mean percentage of positively stained neoplastic cells) were evaluated

\section{Statistical analysis}

Analyses were performed using SPSS version 23 (IBM Corp., Armonk, New York, USA). The significance of differences in means was calculated using One-way ANOVA and the T-test. Chi-square and Fischer's exact tests were used to assess the significance of differences in clinicopathological characteristics across categories of CDX2 and SOX2 expression. Differences were considered statistically significant whenever the $p<0.05$.

\section{Results}

In this study, 130 paraffin blocks with gastric lesions were enrolled. Seventy-seven patients were male $(59.2 \%)$ and the rest were female $(40.8 \%)$. The mean age for CG patients was 51.92 years and for GC patients were 60.95 years; these values were significantly higher than that of controls (45.20 years) (Table 1 ).

\section{CDX2 immunoreactivity}

Our data revealed that CDX2 immunopositivity and CDX2 expression were significantly associated with male sex in both CG and GC cases (Table 3).

Table 3: Relationship between CDX2 immunostaining and gender

\begin{tabular}{|c|c|c|c|c|c|}
\hline \multirow[t]{2}{*}{$\begin{array}{l}\text { Gender in studied groups } \\
\text { (N.) }\end{array}$} & \multicolumn{3}{|c|}{ CDX2 immunopositivity } & \multicolumn{2}{|c|}{$\begin{array}{l}\text { CDX2 expression } \\
\text { (\% of positive cells) }\end{array}$} \\
\hline & $\begin{array}{l}\text { Positive } \\
\mathrm{n}(\%)\end{array}$ & $\begin{array}{l}\text { Negative } \\
\mathrm{n}(\%)\end{array}$ & $p$ value & Mean \pm SD & $p$ value \\
\hline Chronic gastritis (80) & $40(50)$ & $40(50)$ & & $17.88 \pm 21.36$ & \\
\hline Male (44) & 35 (79.5) & $9(20.5)$ & $p>0.001$ & $27.72 \pm 16.48$ & $p<0.001$ \\
\hline Female (36) & $5(14)$ & $31(86)$ & & $6.94 \pm 11.91$ & \\
\hline Gastric adenocarcinoma (40) & $37(92.5)$ & $3(7.5)$ & & $50.38 \pm 25.53$ & \\
\hline Male (26) & $26(100)$ & 0 & $p>0.05$ & $56.07 \pm 25.52$ & $p>0.05$ \\
\hline Female (14) & $11(78.6)$ & $3(21.4)$ & & $47.31 \pm 18.23$ & \\
\hline
\end{tabular}

CDX2 immunopositivity showed a significant difference between studied groups, while it was undetectable in controls; $50 \%$ of CG cases and $92.5 \%$ of GC cases were CDX2 positive. Moreover, CDX2 expression was significantly increased from 0 in controls to $18.37 \%$ in CG to $50.38 \%$ in GC cases (Table 4) (Figure 1).

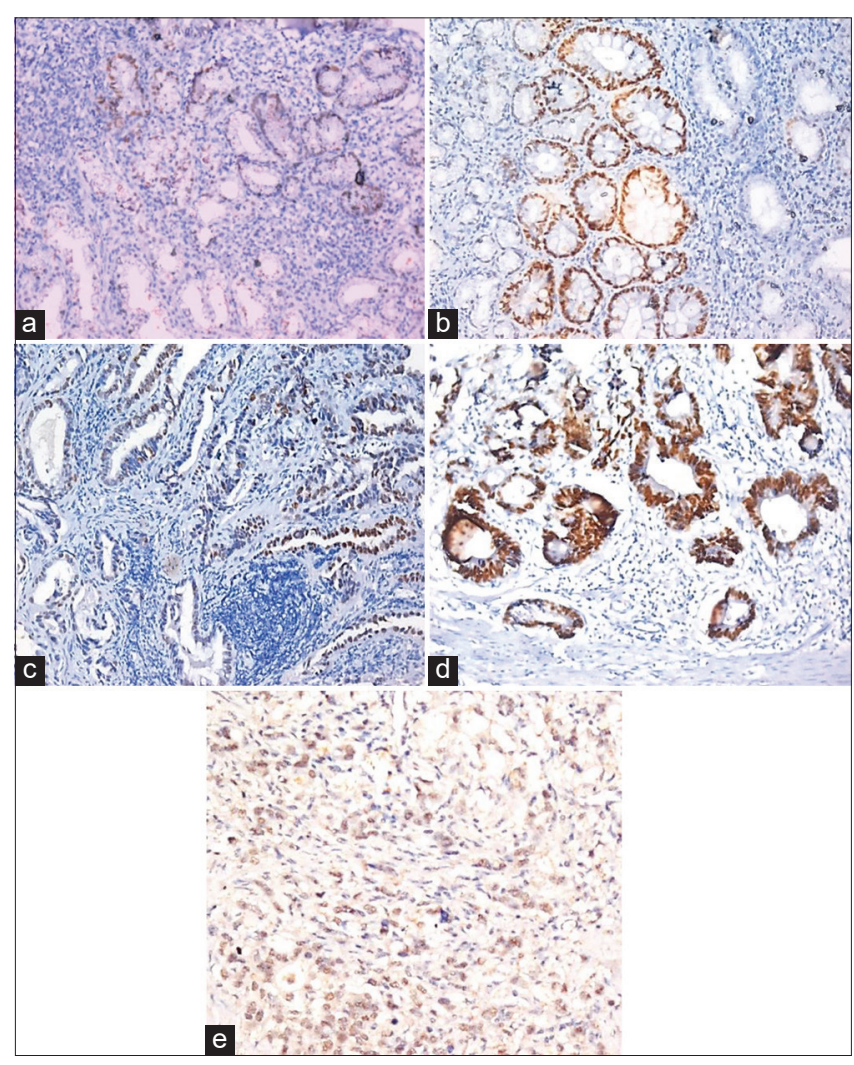

Figure 1: Immunohistochemical expression of CDX2. (a) Moderate chronic gastritis with Helicobacter pylori, positivity in $\sim 40 \%$ of gastric cells ( $\times 200)$, (b) Moderate chronic gastritis with intestinal metaplasia, positivity in $\sim 40 \%$ of gastric cells $(\times 200)$, (c) Moderate chronic gastritis with intestinal metaplasia and dysplasia, positivity in 80\% of gastric cells (×200), (d) Low-grade intestinal-type gastric cancer, positivity in $\sim 80 \%$ of malignant gastric cells $(\times 200)$, (e) High-grade intestinal-type gastric cancer, positivity in $\sim 60 \%$ of malignant gastric cells (200)

Regarding CG cases, CDX2 immunopositivity and expression were significantly associated with the intensity of inflammation, $H$. pylori infection, IM, and dysplasia (Table 4).

Notably, there was a significant increase in CDX2 expression in CG cases with IM (30\%) to dysplasia $(47.5 \%)$ then to carcinoma $(50.38 \%)$ (Table 4$)$.

Regarding intestinal-type GC cases, CDX2 immunopositivity was higher in low grade and earlystage cancers as well as cancers negative for vascular emboli compared with their counterparts, but these relationships did not achieve significant values. On the other hand, CDX2 expression was significantly associated with low grade and early-stage cancers (Table 4).

\section{SOX2 immunoreactivity}

Our data revealed that the immunopositivity and expression of SOX2 were significantly higher in males than in females regarding GC cases (Table 5).

We found SOX2 immunopositivity in $70 \%$ of control cases in scattered foci of foveolar cells. Only $22.5 \%$ of CG cases were positive for SOX2 compared 
Table 4: CDX2 immunostaining in studied groups

\begin{tabular}{|c|c|c|c|c|c|c|c|}
\hline \multirow[t]{2}{*}{ Diagnosis (n.) } & & & \multicolumn{3}{|c|}{ CDX2 immunopositivity } & \multicolumn{2}{|c|}{ CDX2 expression (\% of positive cells) } \\
\hline & & & Positive n (\%) & Negative n (\%) & $\mathrm{p}$ value & Mean \pm SD & $p$ value \\
\hline Control (10) & & & 0 & 10 & $p<0.01$ & $00 \pm 00$ & $p>0.001$ \\
\hline Chronic gastritis (80) & & & $40(50)$ & $40(50)$ & & $18.37 \pm 17.86$ & \\
\hline Intensity of inflammation & & $\begin{array}{l}\text { Mild (28) } \\
\text { Moderate (52) }\end{array}$ & $\begin{array}{l}8(28.6) \\
32(61.5)\end{array}$ & $\begin{array}{l}20(71.4) \\
20(38.5)\end{array}$ & $p<0.01$ & $\begin{array}{l}10.17 \pm 8.66 \\
22.79 \pm 19.93\end{array}$ & $p>0.01$ \\
\hline Associated lesions & H. pylori infection & $\begin{array}{l}\text { Present (44) } \\
\text { Absent (36) }\end{array}$ & $\begin{array}{l}27(61.4) \\
13(36)\end{array}$ & $\begin{array}{l}17(38.6) \\
23(64)\end{array}$ & $p<0.05$ & $\begin{array}{l}23.52 \pm 15.27 \\
12.08 \pm 18.95\end{array}$ & $p>0.01$ \\
\hline & IM & Present (34) & $27(79.4)$ & $7(20.6)$ & $p<0.001$ & $30.00 \pm 17.71$ & $p>0.001$ \\
\hline & Dysplasia & $\begin{array}{l}\text { Absent (46) } \\
\text { Present (10) } \\
\text { Absent (70) }\end{array}$ & $\begin{array}{l}13(28.3) \\
10(100) \\
30(43)\end{array}$ & $\begin{array}{l}33(71.7) \\
0 \\
40(57)\end{array}$ & $p<0.001$ & $\begin{array}{l}9.78 \pm 12.34 \\
47.50 \pm 6.34 \dagger \\
14.21 \pm 14.81\end{array}$ & $p>0.001$ \\
\hline Intestinal-type GC (40) & & & $37(92.5)^{*}$ & $3(7.5)$ & & $50.38 \pm 25.53^{*}, \ldots, \S$ & \\
\hline Grade of differentiation & & $\begin{array}{l}\text { Low grade (29) } \\
\text { High grade (11) }\end{array}$ & $\begin{array}{l}28(96.6) \\
9(81.8)\end{array}$ & $\begin{array}{l}1(3.4) \\
2(18.2)\end{array}$ & $p>0.05$ & $\begin{array}{l}61.38 \pm 19.73 \\
21.36 \pm 13.25\end{array}$ & $p>0.001$ \\
\hline Stage of invasion & & $\begin{array}{l}\text { Early stage (27) } \\
\text { Advanced stage (13) }\end{array}$ & $\begin{array}{l}26(96.3) \\
11(84.6)\end{array}$ & $\begin{array}{l}1(3.7) \\
2(15.4)\end{array}$ & $p>0.05$ & $\begin{array}{l}60.74 \pm 20.12 \\
28.85 \pm 22.28\end{array}$ & $p>0.001$ \\
\hline Vascular invasion & & $\begin{array}{l}\text { Present (33) } \\
\text { Absent (7) }\end{array}$ & $\begin{array}{l}30(91) \\
7(100)\end{array}$ & $\begin{array}{l}3(9) \\
0\end{array}$ & $p>0.05$ & $\begin{array}{l}48.03 \pm 27.24 \\
61.43 \pm 10.29\end{array}$ & $p>0.05$ \\
\hline
\end{tabular}

Table 5: Relationship between soX2 immunostaining and gender

\begin{tabular}{|c|c|c|c|c|c|}
\hline \multirow[t]{2}{*}{$\begin{array}{l}\text { Gender in studied } \\
\text { groups (n.) }\end{array}$} & \multicolumn{3}{|c|}{ SOX2 immunopositivity } & \multicolumn{2}{|c|}{$\begin{array}{l}\text { SOX2 expression (\% of } \\
\text { positive cells) }\end{array}$} \\
\hline & $\begin{array}{l}\text { Positive } \\
\mathrm{n}(\%)\end{array}$ & $\begin{array}{l}\text { Negative } \\
\mathrm{n}(\%)\end{array}$ & $p$ value & Mean \pm SD & $p$ value \\
\hline Control (10) & & & & $9.00 \pm 6.58$ & \\
\hline Male (7) & $4(57)$ & $3(43)$ & $p<0.05$ & $10.71 \pm 5.35$ & $p<0.05$ \\
\hline Female (3) & $3(100)$ & 0 & & $5.0 \pm 8.66$ & \\
\hline Chronic gastritis (80) & & & & $52.38 \pm 28.82$ & \\
\hline Male (44) & $10(22.7)$ & $34(77.3)$ & $p>0.05$ & $13.41 \pm 25.78$ & $p<0.05$ \\
\hline Female (36) & $8(22.2)$ & $28(77.8)$ & & $9.17 \pm 19.44$ & \\
\hline \multicolumn{6}{|l|}{ Intestinal-type GC (40) } \\
\hline Male $(26)$ & $25(96.2)$ & $1(3.8)$ & $p<0.001$ & $60.96 \pm 16.91$ & $p<0.01$ \\
\hline Female (14) & $7(50)$ & $7(50)$ & & $36.43 \pm 39$ & \\
\hline
\end{tabular}

to positivity in $80 \%$ intestinal-type GC with a significant difference between both groups (Table 6). Furthermore, SOX2 expression significantly increased from $11.5 \%$ in CG to $52.38 \%$ in intestinal-type GC (Figure 2).

In CG cases, intensity of inflammation - either mild or moderate - did not affect immunoreactivity for SOX2. CG with dysplasia significantly showed higher SOX2 immunopositivity and expression than in CG without dysplasia (Table 6).

Regarding intestinal-type GC cases, SOX2 immunopositivity was higher in high grade and in advanced stage GCs than with low grade and earlystage cancers, but with no statistically significant difference. However, we found that SOX2 expression was significantly increased in high grade and advanced-stage cancers compared with low grade and early-stage cancers. Vascular invasion did not affect immunoreactivity for SOX2 (Table 6).

\section{Discussion}

Considering GC as one of the main cancercausing deaths and being a disease with multiple outcomes that cannot be predicted by clinicopathological features alone [17], finding precise prognostic factors in patients with GC is an urgent need. Moreover, GC represents an example of inflammation-linked cancer.

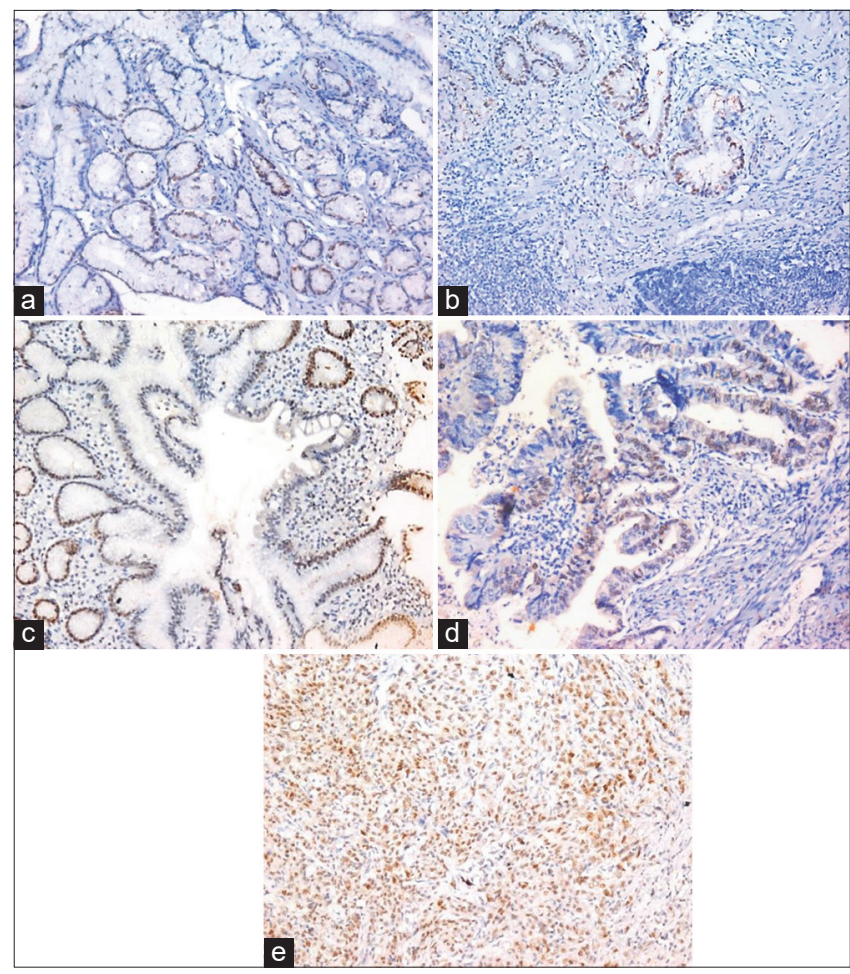

Figure 2: Immunohistochemical expression of SOX2. (a) Mild chronic gastritis, positivity in $\sim 40 \%$ of gastric cells (×200), (b) Moderate chronic gastritis with Helicobacter pylori, positivity in $~ 30 \%$ of gastric cells (×200), (c) Chronic gastritis with $\mathrm{H}$. pylori and intestinal metaplasia, positivity in $\sim 30 \%$ of gastric cells $(\times 200)$, (d) Low-grade intestinal-type gastric cancer, positivity in $\sim 40 \%$ of malignant gastric cells (×200), (e) High-grade intestinal-type gastric cancer, positivity in $\sim 80 \%$ of malignant gastric cells $(\times 200)$

The progression of $H$. pylori-infected CG facilitates the development of IM, which has been extensively studied as a premalignant condition of gastric carcinoma [18].

In this study, we assess immunoreactivity of CDX2 and SOX2 in different gastric lesions according to the number of positive cases (immunopositivity) and mean percentage of positive gastric and tumor cells (expression). CDX2 and SOX2 were considered immunopositive when immunoreactivity was observed in $>5 \%$ of gastric/tumor cells, leading to a higher prevalence of CDX2 and SOX2 immunopositivity in our study $(92.5 \%$ and $80 \%$, respectively) than that 
Table 6: SOX2 Expression in studied groups

\begin{tabular}{|c|c|c|c|c|c|c|c|}
\hline \multirow[t]{2}{*}{ Diagnosis (N.) } & & & \multicolumn{3}{|c|}{ SOX2 immunopositivity } & \multicolumn{2}{|c|}{ SOX2 expression (\% of positive cells) } \\
\hline & & & Positive n (\%) & Negative $\mathrm{n}(\%)$ & $p$ value & Mean \pm SD & $\mathrm{p}$ value \\
\hline Control (10) & & & $7(70)$ & $3(30)$ & $p<0.001$ & $9.00 \pm 6.58$ & $p>0.05$ \\
\hline Chronic gastritis (80) & & & $18(22.5)$ & $62(77.5)$ & & $11.50 \pm 23.10$ & \\
\hline Intensity of inflammation & & $\begin{array}{l}\text { Mild (28) } \\
\text { Moderate (52) }\end{array}$ & $\begin{array}{l}6(21.4) \\
12(23)\end{array}$ & $\begin{array}{l}22(78.6) \\
40(77)\end{array}$ & $p>0.05$ & $\begin{array}{l}13.21 \pm 26.25 \\
10.58 \pm 21.43\end{array}$ & $p>0.05$ \\
\hline Associated lesions & H. pylori infection & $\begin{array}{l}\text { Present (44) } \\
\text { Absent (36) }\end{array}$ & $\begin{array}{l}5(11.4) \\
13(36)\end{array}$ & $\begin{array}{l}39(88.6) \\
23(64)\end{array}$ & $p<0.01$ & $\begin{array}{l}p>0.05 \\
16.67 \pm 24.93\end{array}$ & $p>0.05$ \\
\hline & IM & $\begin{array}{l}\text { Present (34) } \\
\text { Absent (46) }\end{array}$ & $\begin{array}{l}6(17.6) \\
12(26)\end{array}$ & $\begin{array}{l}28(82.4) \\
34(74)\end{array}$ & $p>0.05$ & $\begin{array}{l}8.53 \pm 17.21 \\
13.7 \pm 26.61\end{array}$ & $p>0.05$ \\
\hline & Dysplasia & $\begin{array}{l}\text { Present (10) } \\
\text { Absent (70) }\end{array}$ & $\begin{array}{l}5(50)^{\dagger} \\
13(18.6)\end{array}$ & $\begin{array}{l}5(50) \\
57(81.4)\end{array}$ & $p<0.05$ & $\begin{array}{l}28 \pm 31.2^{\ddagger} \\
9.14 \pm 20.95\end{array}$ & $p>0.01$ \\
\hline Intestinal-type GC (40) & & & $32(80)^{\star \delta,\|.\|}$ & $8(20)$ & & $52.38 \pm 28.82^{*, * *}$ & \\
\hline Grade of differentiation & & $\begin{array}{l}\text { Low Grade (29) } \\
\text { High Grade (11) }\end{array}$ & $\begin{array}{l}22(76) \\
10(91)\end{array}$ & $\begin{array}{l}7(24) \\
1(9)\end{array}$ & $p>0.05$ & $\begin{array}{l}44.14 \pm 25.85 \\
77.73 \pm 28.93\end{array}$ & $p>0.05$ \\
\hline Stage of invasion & & $\begin{array}{l}\text { Early Stage (27) } \\
\text { Advanced stage (13) }\end{array}$ & $\begin{array}{l}20(74.1) \\
12(92.3)\end{array}$ & $\begin{array}{l}7(25.9) \\
1(7.7)\end{array}$ & $p>0.05$ & $\begin{array}{l}42.59 \pm 26.11 \\
72.69 \pm 23.68\end{array}$ & $p>0.001$ \\
\hline Vascular invasion & & $\begin{array}{l}\text { Present (33) } \\
\text { Absent (7) }\end{array}$ & $\begin{array}{l}25(75.8) \\
7(100)\end{array}$ & $\begin{array}{l}8(24.2) \\
0\end{array}$ & $p>0.05$ & $\begin{array}{l}51.97 \pm 31.74 \\
54.29 \pm 4.50\end{array}$ & $p>0.05$ \\
\hline
\end{tabular}

N: Number, H. pylori: Helicobacter pylori, IM: Intestinal metaplasia, GC: Gastric cancer, ${ }^{\dagger} p<0.05$ compared to IM, ${ }^{*} p<0.001$ compared to control and CG, ${ }^{5, \|} p<0.05$ and $p<0.001$ compared to dysplasia and IM, respectively, ${ }^{\ddagger} \mathrm{p}<0.01$ compared to IM, ${ }^{* *} \mathrm{p}<0.05$ and $\mathrm{p}<0.001$ compared to dysplasia and IM, respectively.

reported in other studies as Bao et al. [19] (35.1\%), Fan et al. [20] ( 76\%), and Harras and Mowafy [21] $(81.25 \%)$ regarding CDX2 immunopositivity, and studies by Camilo et al. [22] (52\%) and Yang et al. [23] $(41.7 \%)$ regarding SOX2 immunopositivity.

Clinicians encounter sex disparities in diagnostic and therapeutic responses. Data in our study revealed that male:female ratio was 1.2:1 in CG cases and 1.9:1 in GC cases. Furthermore, we found an association between male sex and both CDX2 and SOX2 expression. This is in line with the findings of Bao et al. [19] and Camilo et al. [22].

In our study, the mean age for intestinal-type GC cases was of 60.95 years, with male:female ratio 1.9:1. However, Saha et al. [24], in their study, found a median age of 55 years with male:female ratio of 2.7:1. In Halder et al. [11] study, the mean age was 51.16 years with a male:female ratio of 1.63:1.

In the current study, CDX2 was undetectable in control cases, this goes with studies of Fan et al. [20] and Bao et al. [19], who reported negative CDX2 staining in normal gastric mucosa and stromal cells. CDX2 immunopositivity and expression were sequentially increased from CG to intestinal-type GC. This is parallel to the fact that $\mathrm{GC}$ is one of the inflammation-linked cancers [25].

In concordance with Saito et al. [26], who reported a relationship between CDX2 expression and intensity of inflammation, we found a significant association between CDX2 (immunopositivity and expression) with a moderate intensity of inflammation in $C G$ cases.

In our study, CDX2 immunopositivity was significantly higher in $H$. pylori positive cases than negative ones, a finding consistent with previous reports which have shown that $H$. pylori induces CDX2 expression in the human stomach before the development of IM [9], [27]. Several studies have demonstrated that $H$. pylori infection leads to the expression of CDX2 in areas of IM and also in foci of non-metaplastic cells [28], [29]. However, other studies have demonstrated that CDX2 expression is higher in $H$. pylori-negative patients than positive patients [30], [31].

As an intestine-specific transcription factor, CDX2 has a key role in regulating the proliferation and differentiation of intestinal cells and maintaining intestinal phenotypes in the gastric epithelium [19], [32]. Consistent with this literature, we found a significantly higher CDX2 immunopositivity and expression in CG with IM than cases without IM.

Reinforcing the role of CDX2 as a biomarker of progression in the preneoplastic stages of gastric carcinogenesis, we observed a significant increase in CDX2 expression from IM to dysplasia, this matches the finding of Camillo et al. [33] that CDX2 is acquired de novo in IM and maintained in dysplasia, on the contrary, Kim et al. [34] observed a significant reduction in CDX2 expression in the foci of gastric epithelial dysplasia when compared with the adjacent metaplastic gastric mucosa.

We found that all cases of CG associated with dysplasia were immunopositive for CDX2. Similarly, Rugge et al. [35] reported positive CDX2 expression in all their studied dysplastic lesions. Although we observed a gradual decrease of CDX2 immunopositivity from dysplasia to early GCs to advanced cancers, CDX2 expression increased from dysplasia to early GC then reduced in advanced cancers. In contrast to our results, Mizoshita et al. [36] reported a gradual decrease of CDX2 expression from dysplasia to early to advance GCs. This controversy can be attributed to the small number of our dysplastic lesions. Immunopositivity and expression of CDX2 between dysplasia and cancer were not different. The same finding was reported by Kang et al. [32].

Regarding CDX2 expression in GC, we found CDX2 immunopositivity in $92.5 \%$ of studied GC cases. It has been suggested that the intestinal-type gastric carcinoma may be transformed from IM [37]. This may account for the high positivity of CDX2 in intestinaltype gastric carcinomas. However, we found lower expression in high grade and advanced-stage cancers than in low grade and early-stage ones. This 
is consistent with previous reports by Satio et al. [25] and Wang et al. [38], which stated that CDX2 was expressed more at a low grade and early stage of gastric carcinogenesis intestinal phenotypic elements and could be associated with the shift from gastric to intestinal phenotype expression. In a study done by Qin et al. [39], a significant negative association between expression of CDX2 and stage of GC was detected and also they found CDX2 positive patients had longer survival than those who were CDX2 negative. Mizoshita et al. [40] also reported that CDX2 expression was associated with a favorable outcome. Furthermore, Roessler et al. [41] indicated that reduction of CDX2 may represent a marker of tumor progression.

Consistent with Bao et al. [19], we did not find a correlation between CDX2 immunopositivity and CDX2 expression with vascular invasion.

SOX2 can act both as an oncogene and a tumor suppressor in different types of cancer, suggesting that the role of transcription factors in cancer initiation may depend on several factors, including the other oncogenic mutations involved in cell transformation and the cell type of origin [42]. Although transcription factors are not classical drug targets, approaches to SOX2targeted therapy are already being addressed in breast cancer [43].

In the current study, we found SOX2 expression in scattered deep gastric glands of control cases. This was in agreement with Camilo et al. [33], who reported a consistent SOX2 expression in normal gastric mucosa, mostly in the neck region. Then, SOX2 expression was observed in CG and increased significantly in intestinal-type GC cases. These findings identified that SOX2 expression was evident in normal mucosa and maintained in $C G$ and $G C$, which reinforce its association with gastric differentiation. Our results were consistent with previous literature by Basat et al. [44] and Hutz et al. [45], who reported significant SOX2 overexpression in GC relative to the adjacent normal tissues, concluding that SOX2 has a potential role on oncogenesis, epithelial to mesenchymal transition, tumor progression, and metastasis. However, other studies reported downregulated SOX2 expression in gastric tumor tissue and suggested that SOX2 can function as a tumor suppressor by regulating the cell cycle and apoptosis [46], [47]. This paradoxical role of SOX2 in GC was reported by Carrasco-Garcia et al. [48].

We found lower SOX2 immunopositivity and expression in CG with $H$. pylori than in negative ones. This goes with the results of Camilo et al. [33] and Yoon et al. [49], who stated that SOX2 expression is strongly downregulated by $H$. pylori and attributed this finding to $H$. pylori CagA protein, which induces decreasing in SOX2 expression and increasing CDX2 expression.

In agreement with Tsukamoto et al. [50], we detected lower SOX2 expression in CG with IM than those without. SOX2 and CDX2 are inversely expressed in IM, this is explained as SOX2 was suggested as a CDX2 repressor since down-regulating its levels led to upregulation of CDX2 expression [51].

We observed a significant increase in SOX2 expression from IM to dysplasia to intestinal-type GC. These results indicated a link between these lesions based on the profile of SOX2 expression. This observation supported by findings that IM is a lesion that is difficult to reverse or is even a "point of no return" [52].

Our study revealed a significant increase in SOX2 immunopositivity and expression from IM to dysplasia; however, Camilo et al. [33] showed reverse results. Furthermore, we found a gradual increase in SOX2 immunopositivity and expression with progression from dysplasia to low-grade GC to highgrade cancers, suggesting its oncogenic role.

It is well-established that SOX2 is associated with gastric differentiation [14]. According to our results, this is maintained in $\mathrm{GC}$ as we found higher SOX2 immunopositivity and expression in high grade and advanced intestinal-type GCs compared with lower grade and early-stage cancers. This is parallel to the results of Basat et al. [44] and Du et al. [53], who reported a positive association between SOX2 expression with poor differentiation and advanced tumor stage. On the contrary, Lin et al. [54] stated that SOX2 overexpression was associated neither with the overall survival nor with the other clinicopathological factors including grade and stage, while Yang et al. [23] found that SOX2 positive expression was associated with shorter survival in patients at early-stage cancers, but not at an advanced stage. These conflicting results can be attributed to a lack of understanding the role of SOX2 as an oncogene or tumor suppressor in GC.

In accordance with Camilo et al. [22] and Basat et al. [44], we found no significant association between vascular invasion and SOX2 immunoreactivity; however, Du et al. [53] detected a positive correlation between high SOX2 expression with vascular invasion.

SOX2 expression is inversely correlated with CDX2 expression ( $p=0.004, r=-0.242)$. CDX2 was associated with CG with $H$. pylori and with IM as well as intestinal-type GCs with low grade and early stage, while SOX2 was associated with CG without $H$. pylori and without IM as well as intestinal-type GCs of high grade and advanced stage. These results suggest that the progression from normal gastric to IM to intestinaltype GC occurs with a gain of intestinal differentiation and loss of gastric differentiation. These results are in line with Camillo et al. [22]; Cobler et al. [55]; and Yoon et al. [49], who reported that there was a significant inverse correlation between the expression of SOX2 and CDX2 in gastric adenocarcinomas, and SOX2+/CDX2profile was associated with a poorer prognosis. Different studies with mice models suggest that CDX2 negatively regulates SOX2 and also the reverse [56], [57]. 
The present study had several advantages compared to previous studies. First, it investigated CDX2 and SOX2 in CG and GC lesions, while most of the previous studies covered only one of both lesions. Second, it evaluated the effect of $H$. pylori infection and IM associated with CG on the expression of CDX2 and SOX2. However, the study had limitations by the relatively small number of studied cases.

\section{Conclusion}

The inverse relationship between CDX2 and SOX2 suggests that both could be markers for evaluating GC progression and outcome. This study revealed that CDX2 positive expression was related to CG associated with $H$. pylori infection, IM, dysplasia, as well as to more differentiated and less invasive pattern of intestinal-type GC, while SOX2 positive expression was related to $C G$ without $H$. pylori infection or IM as well as to less differentiated and more invasive intestinal-type GC. Hence, both could predict how CG disease will behave over time and plan a suitable line of treatment and could be potential targets for novel therapeutic interventions.

\section{Authors' Contributions}

$\mathrm{NH}$ interpreted all data and wrote the manuscript; $\mathrm{ZO}, \mathrm{TA}$, and $\mathrm{AB}$ designed the content and structure of the manuscript; $M Y, A A$, and MA provided specimens and clinical data needed for this study. MM designed and revised the manuscript. manuscript.

All authors read and approved the final

\section{Data Availability}

The datasets analyzed during the current study are available from the corresponding author on reasonable request.

\section{References}

1. Ferlay J, Colombet M, Soerjomataram I, Mathers C, Parkin DM, Piñeros $\mathrm{M}$, et al. Estimating the global cancer incidence and mortality in 2018: GLOBOCAN sources and methods. Int $J$
Cancer. 2019;144(8):1941-53. https://doi.org/10.1002/ijc.31937 PMid:30350310

2. Ferlay J, Soerjomataram I, Ervik M, Dikshit R, Eser S, Mathers C, et al. Cancer Incidence and Mortality Worldwide: IARC Cancer Base No. 11. GLOBOCAN v1.0. Lyon, France: IARC; 2012. https://doi.org/10.1002/ijc.29210

3. Correa P, Haenszel W, Cuello C, Zavala D, Fontham E, Zarama G, et al. Gastric precancerous process in a high risk population: Cohort follow-up. Cancer Res. 1990;50(15):4737-40. PMid:2369748

4. de Martel C, Ferlay J, Franceschi S, Vignat J, Bray F, Forman D, et al. Global burden of cancers attributable to infections in 2008: A review and synthetic analysis. Lancet Oncol. 2012;13(6):607-15. https://doi.org/10.1016/s1470-2045(12)70137-7

PMid:22575588

5. Plummer M, Franceschi S, Vignat J, Forman D, de Martel C. Global burden of gastric cancer attributable to Helicobacter pylori. Int J Cancer. 2015;136(2):487-90. https://doi.org/10.1002/ ijc.28999

PMid:24889903

6. Nejati S, Karkhah A, Darvish H, Validi M, Ebrahimpour S, Nouri HR. Influence of Helicobacter pylori virulence factors CagA and VacA on pathogenesis of gastrointestinal disorders. Microb Pathog. 2018;117:43-8. https://doi.org/10.1016/j. micpath.2018.02.016

PMid:29432909

7. Camilo V, Barros R, Sousa S, Magalhães AM, Lopes T, Santos AM, et al. Helicobacter pylori and the BMP pathway regulate CDX2 and SOX2 expression in gastric cells. Carcinogenesis. 2012;33(10):1985-92. https://doi.org/10.1093/carcin/bgs233 PMid:22791809

8. Zhang $\mathrm{Y}$, Wang $\mathrm{H}, \mathrm{Bi} \mathrm{C}$, Xiao $\mathrm{Y}$, Liu Z. Expression of CDX2 in gastric cardia adenocarcinoma and its correlation with $\mathrm{H}$. pylori and cell proliferation. Oncotarget. 2016;7(34):54973-82. https:// doi.org/10.18632/oncotarget.10362

PMid:27384681

9. Barros R, Camilo V, Pereira B, Freund JN, David L, Almeida R. Pathophysiology of intestinal metaplasia of the stomach: Emphasis on CDX2 regulation. Biochem Soc Trans. 2010;38(2):358-63. https://doi.org/10.1042/bst038035 PMid:20298183

10. Hryniuk A, Grainger S, Savory JG, Lohnes D. CDX1 and CDX2 function as tumor suppressors. J Biol Chem. 2014;289(48):33343-54. https://doi.org/10.1074/jbc.m114.583823 PMid:25320087

11. Halder A, Kundu M, Das RN, Chatterjee U, Datta C, Choudhuri MK, et al. CDX2 expression in gastric carcinoma: A clinicopathological study. Indian J Med Paediatr Oncol. 2018;39:52-7. https://doi.org/10.4103/ijmpo.ijmpo_49_17

12. Avilion A, Nicolis S, Pevny L, Perez L, Vivian N, Lovell-Badge R. Multipotent cell lineages in early mouse development depend on SOX2 function. Genes Dev. 2003;17(1):126-66. https://doi. org/10.1101/gad.224503

PMid: 12514105

13. Sarkar A, Hochedlinger $K$. The sox family of transcription factors: Versatile regulators of stem and progenitor cell fate. Cell Stem Cell. 2013;12(1):15-30. https://doi.org/10.1016/j. stem.2012.12.007 PMid:23290134

14. Arnold K, Sarkar A, Yram MA, Polo JM, Bronson R, Sengupta S, et al. Sox2(+) adult stem and progenitor cells are important for tissue regeneration and survival of mice. Cell Stem Cell. 2011;9(4):317-29. https://doi.org/10.1016/j.stem.2011.09.001 PMid:21982232 
15. Tian T, Zhang $\mathrm{Y}$, Wang S, Zhou J, Xu S. Sox2 enhances the tumorigenicity and chemoresistance of cancer stem-like cells derived from gastric cancer. J Biomed Res. 2012;26(5):336-45. https://doi.org/10.7555/jbr.26.20120045 PMid:23554769

16. Cameiro F, Fukayama M, Grabsoh H, Yasui W. WHO classification of tumors of the stomach in digestive system tumors. In: WHO Classification of Tumors. $5^{\text {th }}$ ed. Geneva, Switzerland: WHO Classification of Tumors Editorial Board; 2019. p. 60-110. https://doi.org/10.1007/978-3-7091-6821-9_2

17. Park DI, Yun JW, Park JH, Oh SJ, Kim HJ, Cho YK, et al. HER-2/ neu amplification is an independent prognostic factor in gastric cancer. Dig Dis Sci 2006;51(8):1371-9. https://doi.org/10.1007/ s10620-005-9057-1

\section{PMid: 16868827}

18. Correa P. Human gastric carcinogenesis: A multistep and multifactorial process--first American cancer society award lecture on cancer epidemiology and prevention. Cancer Res. 1992;52(24):6735-40.

PMid: 1458460

19. Bao Q, Dai N, Liu Y, Sun Y, Huang X, Li J. Expression of Cdx2 is associated with clinicopathologic features and prognosis of gastric carcinoma. Chin J Cancer Res. 2006;18:105-10. https:// doi.org/10.1007/s11670-006-0105-y

20. Fan Z, Li J, Dong B, Huang X. Expression of Cdx2 and hepatocyte antigen in gastric carcinoma: Correlation with histologic type and implications for prognosis. Clin Cancer Res. 2005;11(17):6162-70. https://doi.org/10.1158/1078-0432. ccr-05-0278

21. Harras HF, Mowafy SE. CDX2 and cyclooxygenase-2 immunohistochemical expression in gastric carcinoma: Relationship with clinicopathological features. Egypt J Pathol. 2019;39:123-30.

22. Camilo V, Barros R, Celestino R, Castro P, Vieira J, Teixeira MR, et al. Immunohistochemical molecular phenotypes of gastric cancer based on SOX2 and CDX2 predict patient outcome. BMC Cancer. 2014;14:753. https://doi.org/10.1186/1471-2407-14-753 PMid:25300947

23. Yang L, Xu JF, Kang Q, Li AQ, Jin P, Wang X, et al. Predictive value of stemness factor Sox2 in gastric cancer is associated with tumor location and stage. PLoS One. 2017;12(1):e0169124. https://doi.org/10.1371/journal.pone.0169124 PMid:28046028

24. Saha AK, Maitra S, Hazra SC. Epidemiology of gastric cancer in the gangetic areas of West Bengal. ISRN Gastroenterol. 2013;2013:823483. https://doi.org/10.1155/2013/823483 PMid:24251042

25. Plummer M, de Martel C, Vignat J, Ferlay J, Bray F, Franceschi S Global burden of cancers attributable to infections in 2012: A synthetic analysis. Lancet Glob Health 2016;4(9):e609-16. https://doi.org/10.1016/s2214-109x(16)30143-7 PMid:27470177

26. Saito M, Okayama H, Saito K, Ando J, Kumamoto K, Nakamura I, et al. CDX2 is involved in microRNA-associated inflammatory carcinogenesis in gastric cancer. Oncol Lett. 2017;14(5):618490. https://doi.org/10.3892/ol.2017.6956

\section{PMid:29113265}

27. Asano N, Imatani A, Watanabe T, Fushiya J, Kondo Y, Jin X, et al. $\mathrm{Cdx} 2$ expression and intestinal metaplasia induced by $\mathrm{H}$. pylori infection of gastric cells is regulated by NOD1-mediated innate immune responses. Cancer Res. 2016;76(5):1135-45. https:// doi.org/10.1158/0008-5472.can-15-2272

PMid:26759244

28. Bornschein J, Wex T, Peitz U, Kuester D, Roessner A, Malfertheiner $P$. The combined presence of $H$. pylori infection and gastro-oesophageal reflux disease leads to an up-regulation of CDX2 gene expression in antrum and cardia. J Clin Pathol 2009;62(3):254-9. https://doi.org/10.1136/jcp.2008.060061 PMid: 19251954

29. Xiao FM, Sun $Y$, Tian H. CDX2 expression in gastric samples and correlation with $H$. pylori infection. Gastric Liver Dis. 2009;18:550-2.

30. Vauhkonen M, Vauhkonen $\mathrm{H}$, Sipponen P. Helicobacter pylori infection induces a reversible expression of the CDX2 transcription factor protein in human gastric epithelium. Scand J Gastroenterol. 2008;43(8):915-21. https://doi. org/10.1080/00365520802014841

PMid:19086163

31. Shiotani $A$, Uedo $N$, lishi $H$, Tatsuta $M$, Ishiguro $S$, Nakae $Y$, et al. Re-expression of sonic hedgehog and reduction of CDX2 after Helicobacter pylori eradication prior to incomplete intestinal metaplasia. Int J Cancer. 2007;121(6):1182-9. https:// doi.org/10.1002/ijc.22835

PMid:17520681

32. Kang JM, Lee BH, Kim N, Lee HS, Lee HE, Park JH, et al. CDX1 and CDX2 expression in intestinal metaplasia, dysplasia and gastric cancer. J Korean Med Sci. 2011;26(5):647-53. https:// doi.org/10.3346/jkms.2011.26.5.647

PMid:21532856

33. Camilo V, Garrido M, Valente P, Ricardo S, Amaral AL, Barros $\mathrm{R}$, et al. Differentiation reprogramming in gastric intestinal metaplasia and dysplasia: Role of SOX2 and CDX2. Histopathology. 2015;66(3):343-50. https://doi.org/10.1111/ his. 12544

PMid:25196071

34. Kim HS, Lee JS, Freund JN, Min KW, Lee JS, Kim W, et al CDX-2 homeobox gene expression in human gastric carcinoma and precursor lesions. J Gastroenterol Hepatol. 2006;21(2):43842. https://doi.org/10.1111/j.1440-1746.2005.03933.x PMid:16509871

35. Rugge M, Ingravallo G, Farinati F, Russo VM, Zaninotto G, Alvisi V. Re: CDX2 homeotic gene expression in gastric noninvasive neoplasia. Am J Surg Pathol. 2004;28(6):834-5. PMid:15166679

36. Mizoshita T, Tsukamoto T, Nakanishi H, Inada K, Ogasawara N, Joh $\mathrm{T}$, et al. Expression of $\mathrm{Cdx} 2$ and the phenotype of advanced gastric cancers: Relationship with prognosis. J Cancer Res Clin Oncol. 2003;129(12):727-34. https://doi.org/10.1007/ s00432-003-0499-6 PMid: 14557879

37. Fuchs CS, Mayer RJ. Gastric carcinoma. N Engl J Med. 1995;333(1):32-41.

PMid:7776992

38. Wang XT, Wei WY, Kong FB, Lian C, Luo W, Xiao Q, et al. Prognostic significance of CDX2 immunohistochemical expression in gastric cancer: A meta-analysis of published literatures. J Exp Clin Cancer Res. 2012;31(1):98. https://doi. org/10.1186/1756-9966-31-98

PMid:23181722

39. Qin R, Wang NN, Chu J, Wang X. Expression and significance of homeodomain protein $\mathrm{Cdx} 2$ in gastric carcinoma and precancerous lesions. World J Gastroenterol. 2012;18(25):3296-302.

PMid:22783055

40. Mizoshita T, Tsukamoto T, Inada K, Ogasawara N, Hirata A, Kato $\mathrm{S}$, et al. Immunohistochemically detectable $\mathrm{Cdx} 2$ is present in intestinal phenotypic elements in early gastric cancers of both differentiated and undifferentiated types, with no correlation to non-neoplastic surrounding mucosa. Pathol Int. 2004;54(6):392400. https://doi.org/10.1111/j.1440-1827.2004.01647.x 
PMid:15144397

41. Roessler K, Mönig SP, Schneider PM, Hanisch FG, Landsberg S, Thiele J, et al. Co-expression of CDX2 and MUC2 in gastric carcinomas: Correlations with clinico-pathological parameters and prognosis. World J Gastroenterol. 2005;11(21):3182-8. https://doi.org/10.3748/wjg.v11.i21.3182

PMid:15929165

42. Sarkar A, Huebner AJ, Sulahian R, Anselmo A, Xu X, Flattery K. Sox2 suppresses gastric tumorigenesis in mice. Cell Rep. 2016;16:1929-41. https://doi.org/10.1016/j.celrep.2016.07.034 PMid:27498859

43. Stolzenburg S, Rots MG, Beltran AS, RivenbarkAG, Yuan X, Qian $\mathrm{H}$, et al. Targeted silencing of the oncogenic transcription factor SOX2 in breast cancer. Nucleic Acids Res. 2012;40(14):672540. https://doi.org/10.1093/nar/gks360

\section{PMid:22561374}

44. Basati G, Mohammadpour H, Razavi AE. Association of high expression levels of SOX2, NANOG, and OCT4 in gastric cancer tumor tissues with progression and poor prognosis. J Gastroint Can. 2020;51:41-7. https://doi.org/10.1007/ s12029-018-00200-x PMid:30628031

45. Hütz K, Mejías-Luque R, Farsakova K, Ogris M, Krebs S, Anton $\mathrm{M}$, et al. The stem cell factor SOX2 regulates the tumorigenic potential in human gastric cancer cells. Carcinogenesis. 2014;35(4):942-50. https://doi.org/10.1093/ carcin/bgt410

PMid:24325912

46. Wang S, Tie J, Wang R, Hu F, Gao L, Wang W, et al. SOX2, a predictor of survival in gastric cancer, inhibits cell proliferation and metastasis by regulating PTEN. Cancer Lett. 2015;358(2):2109. https://doi.org/10.1016/j.canlet.2014.12.045। PMid:25543086

47. Khalili M, Vasei M, Khalili D, Alimoghaddam K, Sadeghizadeh M, Mowla SJ. Downregulation of the genes involved in reprogramming (SOX2, c-MYC, miR-302, miR-145, and P21) in gastric adenocarcinoma. J Gastrointest Cancer. 2015;46(3):2518. https://doi.org/10.1007/s12029-015-9695-2 PMid:25904219

48. Carrasco-Garcia E, Santos JC, Garcia I, Brianti M, GarcíaPuga M, Pedrazzoli J, et al. Paradoxical role of SOX2 in gastric cancer. Am J Cancer Res. 2016;6(4):701-13. PMid:27186426

49. Yoon JH, Choi SS, Kim O, Choi WS, Park YK, Nam SW, et al. Inactivation of NKX6.3 in the stomach leads to abnormal expression of CDX2 and SOX2 required for gastric-to-intestinal transdifferentiation. Mod Pathol. 2016;29(2):194-208. https:// doi.org/10.1038/modpathol.2015.150

\section{PMid:26743476}

50. Tsukamoto T, Inada K, Tanaka H, Mizoshita T, Mihara M, Ushijima $\mathrm{T}$, et al. Down-regulation of a gastric transcription factor, Sox2, and ectopic expression of intestinal homeobox genes, $\mathrm{Cdx} 1$ and $\mathrm{Cdx} 2$ : Inverse correlation during progression from gastric/intestinal-mixed to complete intestinal metaplasia. J Cancer Res Clin Oncol. 2004;130(3):135-45. https://doi. org/10.1007/s00432-003-0519-6

PMid:14655050

51. Asonuma S, Imatani A, Asano N, Oikawa T, Konishi H, lijima K, et al. Helicobacter pylori induces gastric mucosal intestinal metaplasia through the inhibition of interleukin-4-mediated HMG box protein Sox2 expression. Am J Physiol Gastrointest Liver Physiol. 2009;297(2):G312-22. https://doi.org/10.1152/ ajpgi.00518.2007

PMid:19520737

52. Barros R, da Costa LT, Pinto-de-Sousa J, Duluc I, Freund JN, David L, et al. CDX2 autoregulation in human intestinal metaplasia of the stomach: Impact on the stability of the phenotype. Gut. 2011;60(3):290-8. https://doi.org/10.1136/ gut.2010.222323

PMid:21148572

53. Du XM, Wang LH, Chen XW, Li YX, Li YC, Cao YW. Prognostic value of Sox2 expression in digestive tract cancers: A metaanalysis. J Huazhong Univ Sci Technol Med Sci. 2016;36(3):30512. https://doi.org/10.1007/s11596-016-1584-9 PMid:27376796

54. Lin S, QiW, Han K, Gan Z, Yao Y, Miu D. Prognostic value of SOX2 in digestive tumors: A meta-analysis. Hepatogastroenterology. 2014;61(133):1274-8.

PMid:25436295

55. Cobler L, Pera M, Garrido M, Iglesias M, de Bolós C. CDX2 can be regulated through the signalling pathways activated by IL-6 in gastric cells. Biochim Biophys Acta. 2014;1839:785-92. https://doi.org/10.1016/j.bbagrm.2014.06.009

PMid:24953186

56. Kuzmichev AN, Kim SK, D'Alessio AC, Chenoweth JG, Wittko IM, Campanati L, et al. Sox2 acts through Sox21 to regulate transcription in pluripotent and differentiated cells. Curr Biol. 2012;22(18):1705-10. https://doi.org/10.1016/j. cub.2012.07.013 PMid:22902753

57. Raghoebir L, Bakker ER, Mills JC, Swagemakers S, Kempen MB, Munck AB, et al. SOX2 redirects the developmental fate of the intestinal epithelium toward a premature gastric phenotype. J Mol Cell Biol. 2012;4(6):377-85. https://doi.org/10.1093/jmcb/ mjs030

PMid:22679103 